\title{
Media parergon, media ergon: An analytical overview of the Grammar and Pragmatics of the Media Language
}

\author{
Rafael Duarte Oliveira Venancio ${ }^{1}$
}

\begin{abstract}
The present work has a central question: how a certain media distinguishes itself from the other communicational and linguistic apparatuses of the world. And with that, he turns on the big question of what each media practice would be. The hypothesis defended here is that each type of media, in its definition, is a language and not an apparatus. Using the concepts of Ludwig Wittgenstein, Jacques Derrida, Jean-François Lyotard and John R. Searle, the concepts of parergon and ergon are discussed. Thus, there is the consideration that if the study of the parergon is a logical study, close to the philosophical debates of the Analytical Philosophy and of authors of Continental Philosophy that quoted Wittgenstein, the study of ergon is a pragmatic study, focused on the speech acts. Logic and Pragmatics do not enter here as competitors, but rather as analytical partners in the definition and study of a language. While the first one analyzes the clipping modes, the second analyzes the action made possible by its clipping.
\end{abstract}

Keywords: Philosophy of Language, Media Language, Philosophy of Communication

The present work has a central question: how a certain media distinguishes itself from the other communicational and linguistic apparatuses of the world. And with that, he turns on the big question of what each media practice would be. The hypothesis defended here is that each type of media, in its definition, is a language and not an apparatus.

Now, by checking the media practices in absence - that is, by imitating them outside of their vehicle - we can observe the autonomy of the media languages in relation to the apparatus that, in the limit, is what provides its language status. What moves the media practice are not mechanisms of mechanical transmission and reception, but rather their character of language, their possibilities of "clipping" of the world provided by the concatenation and the specification.

Clearly, any media language allows a clipping of the world even because, given its linguistic ability, it is cut in two ways: (1) it provides an order of things; And (2) it is cut

\footnotetext{
${ }^{1}$ Rafael Duarte Oliveira Venancio, $\mathrm{PhD}$, is professor at Universidade Federal de Uberlândia, Brazil.
} 
off from the world, that is, from other communicational or linguistic devices. These two ways are the two faces of the same cutout, being inseparable. Its conditions of existence and representation consist of this linguistic mechanism.

Such a consideration points to the position of this work within the Analytic Philosophy of Language, more specifically in Wittgensteinian thought and its conception of the nature of language as representation. Here is the order of the grammarian, of the logic of the language games to which we are subjected.

Thus it is erroneous to think that, for example, imagination delimits the frontiers of meaning, and may even expand it. In fact, the imaginability is among the logical criteria already put. Such a grammar is not a 'big mirror'. It does not reflect the essence of things. On the contrary, it is autonomous. It determines the essence of things (BAKER \& HACKER, 2005, p.19). But we can not believe, as $\$ 398$ of Philosophical Investigations puts it, that this grammar is just another form of Vorstellungwelt.

What is important to note here is that we are placed in language, immersed in their games and that everything, in fact, is representation not only because of their lack of autonomy, but because everything is utterances of the logic of the world. We do not own the visual room, nor the Vorstellungwelt, we are part of it. And this is no different with the media.

Thus, the stance of this essay is to treat the media as a language game, and it is possible to draw a grammar. It is through this Media Grammar that we can characterize the media as a language. This Grammar, based on the concept of Wittgenstein, is composed of a dimension of writing - to use the term deconstructionist - that makes it combine two of the three linguistic sectors of the media, represented by the schematic below:

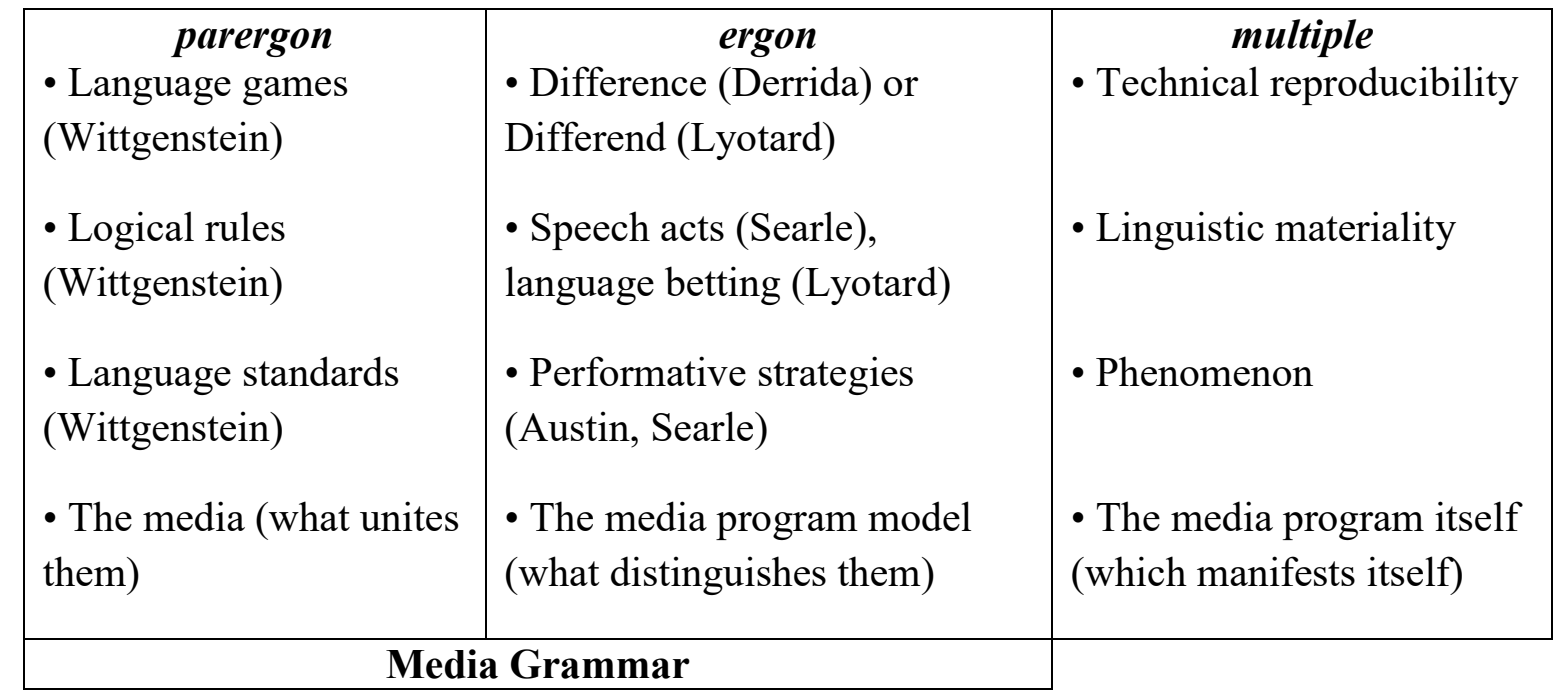


Here, there is a prominent use of the terms parergon and ergon, taken from the derridarian paraesthesia. The concept of parergon is highlighted in Aesthetics with the Critique of Judgment. Kant (2005, p. 45) finds that ornaments (parerga), such as the frames of a painting, although not part of the artistic representation and even undermine the genuine beauty, are essential for a broadening and recognition Of aesthetic taste.

This consideration of Kant - which could even go unnoticed - is taken up by Jacques Derrida in his studies of Aesthetics. In them, Derrida indicates that the parergon of a work of art indicates a need, a lack, that it has in its representational process. What constitutes the parerga, in Derrida's $(1987,59-60)$ reasoning, "is not only its exteriority as an addition, but rather the internal structural connection that fixes it to the inner fault of the work (ergon). And this lack is constitutive of the ergon unit itself. Without this lack, the ergon would not need parergon. Lack of ergon is the lack of a paregon ".

In this way, these ornaments - such as the frame for a painting or a column for a bust - are what make the work of art to be recognized as such. It is the last frontier between what is and what is not. However, the analysis of the parergon only by the letter of Derrida is insufficient to analyze our work within a posture derived from the Analytic Philosophy of Language. What we have with Derrida can be summarized in the following terms: (1) Parergon is a place of (re)presentation, that is, it is through him that we recognize a practice as such. This (re)presentation operates through a cut, a distinction between the work of art and the rest of the world; (2) Parergon is a "function of function". The definition of the work of art provided by the parergon is not the demonstration of an origin (as the tradition represented by Heidegger demonstrates) or of a structure. It is locked in a function. The parergon is nothing more than a function that defines this function; (3) Parergon makes it possible to work in the frame. Using Mallarme's reflection, Derrida demonstrated the possibilities of imitation. Imitation and definition of a work of art are closely linked; And (4) Parergon indicates a logic that relates it to ergon. Derrida calls this situation a "framed violence."

In analyzing the question of the Aesthetics of philosophy from Hegel to the Antiessentialists, the analytical theorists of art, we find nine other interesting points: (1) The Hegelian idea of a formal game, root of understanding of the work of art; (2) The presence of an agonism of language, a strife in the definition of the work of art as demonstrated by Schopenhauer and Nietzsche; (3) The importance of the combinatorial, described by Deleuze, for the definition of the games that cut the (re) presentation. The influence of the Leibnizian idea of a chess at the heart of any representation; (4) Deleuzian 
investigation of language through rules of a play of meanings and meanings; (5) The question of an absence of creation in art. Artistic field as a field of potentialities and combinations as demonstrated by the Kandinsky / Duchamp debate; (6) The definition of what is art or not through the question of an Algebra of function as Duchamp shows in the question of the readymade; (7) The absence of essence in the cut of art before the things of the world as described by the anti-essentialists; (8) The analogy between art and games in the question of their rules. This analogy made by the anti-essentialists, based on the reflection made by the Philosophical Investigations of Wittgenstein; And (9) Finally, the definition of the rules of what an art is or not, through the Wittgensteinian concept of Familienähnlichkeit, as the anti-essentialists preach.

These nine considerations combined with the four derridarian ones, actualize the concept of parergon in the measure that they give to this condition of clipping a linguistic character. That is, not only can it serve questions of language practices, but in the very concept lies a mechanism with such properties.

We thus see that parergon is in reality the locus of a logical cut, which can be seen through mechanisms of language such as combinatorial. In fact, we have come to see that the parergon can be seen as the locus of the language game. It is through a language game that the definition of a particular practice operates. That is, the analysis of the mediatic parergon is an analysis of the game of mediatic language. What makes the media cut from other world practices is its language play, the engendering of rules that relate to each other through similarities.

Ergon, in the theoretical dimension posed by the present work, is linked to the idea of the difference. Now, ergon, as we have seen previously, can not be considered as the work itself, but as a model of work. This work model is defined by the difference, the Lyotardian concept, defined as a strategy to play the language game. For Lyotard, in his work Le Differend, what would be the bet, the outcome of the dispute?

In this view, the actors of an artistic and / or mediatic practice (or any other (re) presentational activity) do not make the rules of the games, they can only act on them. And such action is playing in the form of betting, just as in a card game where playing and betting are interconnected. "When Cézanne uses his brush, what is bet on the painting is called into question; When Schönberg sits on his piano, it's what's in play in music; When Joyce picks up his pen, that's what's in the literature" (LD, §192). In this way, even the most radical movements in the artistic fields are strategies to play within them. There is no creation, only dispute without consensus, fruit of the agonism of language. 
What are formed here are what Lyotard calls the genres of discourse, as can be seen in the citation of $\S 188$ of Le Differend. Each style school is a discourse genre, a strategy of trying to play well (or play poorly) the language game.

Thus the media has a language game, but the mediatic doing is a difference. Media programs alone are multiples. These multiples, mere objects, are the products of media grammar, which in turn, is the broad interactional scope between language games and differences, between rules and ways of playing (of betting, of making their bid).

To analyze the differences, it is necessary to go to the Theory of Speech Acts, part of the Pragmatics of J. L. Austin and John R. Searle. Now, "the starting point of the classical theory of speech acts is the following conviction: the minimum unity of human communication is neither the phrase nor any other expression. It is the performance of some types of acts "(ARMENGAUD, 2006, p. 99). However, in order to look for our project of constructing the grammar of the media language, we have to ask ourselves: what is the basis of these linguistic performances? What are the parameters of this type of action in the language?

Thus, "the theory of speech acts is a systematic study of the relationship between signs and their interpreters. It is about knowing what the interpreters-users do, what acts they perform through the use of certain signs "(ARMENGAUD, 2006, p. Austin divides into three broad groups of speech acts: locutionary, illocutionary, and perlocutionary (AUSTIN, 1975, pp. 109-10). However, it is erroneous to think that performative sentences are limited to those traditional verbs that Austin spends much of his magnus opus analyzing.

With this, Austin draws the idea of a performative force within language. This force would be at the core of any language in full articulation with the propositions that compose it. We find here the origin, the mechanism, of the Lyotardian articulation of the language game through the difference.

However, if Austin found such a force along with the leading role of speech acts in a pragmatic conception of language, it was Searle who, in fact, fulfilled the idea implicit in austinian thought of systematizing these performatives, their strength as their Acts.

In Speech Acts, Searle defines performative force (or illocutionary force) in the form of a function, $F(p)$, "where the variable F stands for the illocutionary force indicating devices as values $\mathrm{p}$ and $\mathrm{p}$ is for expressions for propositions" (Searle 1976, 31).

Thus, in addition to corroborating the participation of the illocutionary force as part of the meaning (SEARLE \& VANDERVEKEN, 2009, p.7), it indicates that in the formula 
F (p) lies the idea of an illocutionary logic that could be the basis of a Universal grammar, as in the sense put by Montague (1970).

However, although we are quite close to the notion that we have developed throughout the present work - that is, grammar is composed of propositions and its rules (parergon / language game) and performativity (ergon / That the idea of the Montague grammar is applied to the Beweissystem (natural language) and not to the Satzsystem (language game). Thus, Searle is thinking here in the languages and not in the linguistic protocols, in the languages that language games make most evidente roles.

In this way, our performative analysis needs to make an adaptation of Searle's ideas. Such a task is possible because, as Ranta (2006: 118) states, Wittgenstein conceived an individual language game as "a unit that has a set of rules that can be formalized in a closed system."

Ranta posits that this closed system (ie satzsystem) can be schematized as beweissystem being, along with Gödel's incompleteness proofs, the two biggest challenges against a vertical universality (between subjects) and opening a possibility for a horizontal universality (between Languages).

In stating this, Ranta seeks the possible translation between language games. This translation is carried in a usual sense, and therefore different from that posed as a possibility by the present work - that is, the horizontal universality between language games in its propositional structure indicated by the analytical method of logical play and its payoffs. However, this is not a subject for this section.

Knowing that the satzsystem can be schematized as a beweissystem for performativity issues, we must then define parameters for such adaptation. Thus, being unable to use only an application of taxonomy and illocutionary logic constructed by Searle to verify the illocutionary force of communicational language games, we must be inspired by their genesis: the 12 differences that make it possible to classify the different types of F in F (p) (Searle, 2002, pp. 2-11). They are:

1. Differences in purpose of (type of) act;

2. Differences in the direction of fit between words and the world;

3. Differences in expressed psychological states;

4. Differences in the force or force with which the illocutionary purpose is presented; 
5. Differences regarding the status or position of the speaker and the listener, insofar as this concerns the illocutionary force of the issue;

6. Differences in how the broadcast relates to the interests of the speaker and the listener;

7. Differences regarding relations with the rest of the discourse;

8. Differences regarding the propositional content determined by the illocutionary force indicators;

9. Differences between acts that should always be acts of speech and those that can, but need not, be performed as acts of speech;

10. Differences between the acts they require and those that do not require extralinguistic institutions for their realization;

11. Differences between the acts in which the corresponding illocutionary verb has a performative use and those in which it does not;

12. Differences regarding the style of realization of the illocutionary act.

Thus, a discourse genre can only be considered as such if it is in reference to these 12 dimensions. The non-demarcation of one of them, for example, may cause a field of undifferentiation of the ergon and with this, for example, hiding nuances of the linguistic action that can be important for a better understanding of a certain language.

Thus, there is the consideration that if the study of the parergon is a logical study, close to the philosophical debates of the Analytical Philosophy and of authors of Continental Philosophy that quoted Wittgenstein, the study of ergon is a pragmatic study, focused on the speech acts. Logic and Pragmatics do not enter here as competitors, but rather as analytical partners in the definition and study of a language. While the first one analyzes the clipping modes, the second analyzes the action made possible by its clipping.

\section{References}

ARMENGAUD, F. A Pragmática. São Paulo: Parábola, 2006.

AUSTIN, J. L. How to do Things with Words. Cambridge: HUP, 1975.

BAKER, G. P \& HACKER, P. M. S. Wittgenstein: Understanding and Meaning (Part II: Exegesis §§1-184). Malden: Blackwell, 2005.

DERRIDA, J. The Truth in Painting. Chicago: University of Chicago Press, 1987.

ECO, U. Estetica e teoria dell'informazione. Milão: Bompiani, 1972.

KANT, I. Critique of Judgment. Mineola: Dover, 2005. 
LYOTARD, J-F. The Differend. Minneapolis: UMP, 2007.

MONTAGUE, R. "Universal Grammar”. Theoria. v. 36, n. 3. Suécia, dezembro/1970.

RAJAGOPALAN, K. Nova Pragmática. São Paulo: Parábola, 2010.

RANTA, A. "Type theory and Universal Grammar". Philosophia Scientiae. CS. 6, Nancy:

Nancy 2, setembro/2006.

SEARLE, J. R. Speech Acts. Cambridge: CUP, 1976.

SEARLE, J. R. Expressão e Significado. São Paulo: Martins Fontes, 2002.

SEARLE, J. R. \& VANDERVEKEN, D. Foundations of illocutionary logic. Cambridge: CUP, 2009.

WITTGENSTEIN, L. Investigações Filosóficas. São Paulo: Nova Cultural, 1999.

WITTGENSTEIN, L. Gramática Filosófica. São Paulo: Loyola, 2003.

WITTGENSTEIN, L. Tractatus Logico-Philosophicus. N. Y.: Harper, 2009. 